\title{
Білорусія та Україна під калейдоскопічним поглядом
}

\author{
Ольга Шитова - Петр Каліна (Брно)
}

\author{
Белоруссия и Украина: история и культура. Выпуск 5. Сборник статей. Редколлегия: М. А. Робинсон \\ (заместитель главного редактора), Е. Ю. Борисенок, Л. Е. Горизонтов, М. Ю. Дронов, Ю. А. \\ Лабынцев, С. С. Лукашова (секретарь), Г. Ф. Матвеев, В. И. Мироненко, К. В. Никифоров, О. А. \\ Остапчук. Москва: Институт славяноведения РАН, 2015. 540 с. ISBN 975-5-7576-0334-6.
}

До уваги філологів, істориків, літературознавців та широкого кола читачів пропонується п'ятий випуск збірника Белоруссия $u$ Украина: история и культура, який був виданий Інститутом славістики Російської академії наук у 2015 році в Москві. Головним редактором та упорядником публікації $є$ російський історик та славіст Борис Миколайович Флоря, який започаткував традицію видання даного збірника ще у 2003 році.

Подібно до попередніх чотирьох видань збірник Білорусія та Украӥна містить наукові статті, в яких переважно російськими та українськими науковцями розглядається широкий спектр питань. Ці питання стосуються, зокрема, культурного та історичного розвитку України та Білорусії з діахронічного погляду на окремо взяту проблематику. Експліцит збірника творять рецензї та історичні огляди.

Книга присвячена як окремим видатним постатям (Самійло Величко, Ігор Кістяковський, Юзеф Пілсудський), так і конкретним історичним подіям, які значною мірою вплинули на подальший культурний і політичний розвиток обох країн, або лінгвістичній тематиці, котра одиночно представлена у статті Тетяни Курохтіної.

Збірник починається дослідженням Boлодимира Івановича Фенича під назвою $\mathrm{Mo}$ настырская Церковъ: происхождение и ранняя история Мукачевского епископства (середина $X V$ в.), присвяченим питанню, сповненого протиріч, а саме, походженню Мукачівської єпархії, котра отримала свою назву від Мукачівського монастиря - духовного центру ві- зантійського обряду на території Угорського королівства. Автор, порівнюючи свідчення видатних вчених та аналізуючи добові документи, охоплює сумнівні початки закладення перших монастирів у сьогоднішній Закарпатській області, службу першого ігумена Мукачівського монастиря Луки, та, закінчуючи своє майже детективне дослідження так званим дипломом короля Владислава, доходить до цікавих висновків. Однак питання, кому ж, все-таки, підкорявся мукачівський єпископ, автор залишає без відповіді. Об'ємною $\epsilon$ наступна стаття Украинское общество XVII века и его элита в „Летописи“ Самойла Величко, автором якої являється упорядник даного збірника. Борис Флоря намагається пунктирно відтворити головні моменти життя однієї 3 найзагадковіших постатей української минувшини та дослідити історію написання Величком його двохтомної монументальної історіографії, а також ї̈ подальшу долю. Проте, цінним $є$, насамперед, зосередження уваги на змісті самого Лimonucy та описі козаків-запорожців і української еліти XVII ст. Борис Миколайович піддає конфронтації Літопис Самійла Величка Літопису Григорія Грабянки, які вважаються так званими козацькими літописами. Автор подає новий і цікавий погляд на дану проблематику. Марія Олександрівна Маханько розглядає тему Культурное влияние Малороссии в черковном искусстве казанской епархии ХVII-ХVIII вв., а саме зростання українського, або ж, як в ті часи називали, «малоросійського» впливу на мистецтво та культуру Казанського краю XVIII ст. Цей вплив найбільше проявився 
в образотворчому мистецтві й архітектурі, про що свідчить бароковий київський архітектурний стиль, творцями якого були, насамперед, випускники одного з найпрестижніших у ті часи навчальних закладів, а саме Києво-Могилянської академії. Стаття Малорусский монархизм и Черная сотня в империи Романовых как часть истории украинского движения була написана Климентієм Климентійовичем Федевичем як реакція на поширене в останніх роках на території Росії твердження, що український народ та український національний рух не є автентичними, і тому не мають право на існування. Так це чи ні, а також що стало основою для розвитку українського національного самоусвідомлення $\epsilon$ головним предметом дослідження автора статті, який в своїх аргументах опирається на достовірні історичні факти. Маріус Орестович Тэрыцэ, єдиний неслов'янський автор, у свойй праці Украиниы Хотинского уезда Бессарабской губернии в Российской империи детально досліджує, оперуючи статистичними даними, демографічну ситуацію Хотинського повіту та його еволюцію протягом 1812-1918 років, включаючи опис динаміки міграційних процесів та просвітництва, віросповідання та релігійної акультурації. Цінними є додатки, у яких автор на основі матричних книг, дотримуючись первісних назв поселень, подає перелік населених пунктів згідно з округами, інформацію про перехід католиків у православну віру, приклади українських і польських прізвищ тощо. Окремо хотілося б відзначити доробок Павла Павловича Гай-Нижника, у котрому він змальовує постать українського державного діяча Ігоря Кістяківського, який у широких колах українців є маловідомою постаттю, а тому внесок Павла Гай-Нижника $€$ важливим для популяризації видатних українських діячів як у самій Україні, так і за ї̈ межами. Наступні два автори з різних позицій розглядають події громадянської війни в Україні протягом 1917-1921 років. Перший з них, Олександр Владленович Шубін, присвятив свою статтю з назвою Начиональный и соииальный состав юго-востока Украины и рево- лючионный прочесс 1917-1921 годов на примере Александровского уезда Екатеринославской губернии подіям громадянської війни на прикладі одного з повітів Катеринославської губернії, а сьогоднішнього Запоріжжя, де і зародився чорний знак анархізму, що згодом став у мультиетнічному середовищі Приазов'я емблемою махновського руху. Наступний автор, Андрій Владиславович Ганин, описує Подготовку кадров украинского Генерального штаба в период Гражданской войны и эмиграиии (19171924 г2.) та негативно оцінює діяльність Симона Петлюри як військового організатора, оскільки головний отаман, за словами автора, не був достатньо компетентний у військових питаннях. Воєнно-революційну тематику продовжує Ірина Василівна Міхутіна. В своїй статті Первые недели польско-советской военной кампании 1920 года авторка характеризує стратегічні дії воюючих сторін та роль Юзефа Пілсудського у даному процесі. Тимур Валерійович Кальченко звертається до іншої проблематики та знайомить читачів з життям Федора Сінькевича, Григорія Прозорова, Михайла Стельмашенка та Тимофія Лященка у доробку з назвою Киевское правое духовенство в эмиграчии: биографические материалы. Наступний автор Олександр Миколайович Вабіщевич дає критичну оцінку Украинской общественно-политической и культурно-простветительской делтельности на Полесье в 1918-1930 годах. Цікавою є стаття Генадія Генадійовича Дедурина Белорусский вектор в политике Юзефа Пилсудского, який даною проблематикою повертає нас до статей воєнно-політичного спрямування. Автор подає характеристику та свою оцінку одній із знакових постатей польської історії. Михайло Андрійович Робінсон торкається філологічних проблем у період білорусизації та українізації. Стаття, яка несе назву Русские ученые-слависты и Белорусская академия наук в 1920-е годы, змальовує просвітницькі дії українських, російських та білоруських вчених під настороженим поглядом владної верхівки та нелегкий шлях зародження мінської наукової інституції. Двійка авторів у складі Тетяни Павлівни Хлиніної 
та Ігоря Юрійовича Васильєва торкнулася історико-політичного питання у статті Украинизачия на Кубани: замыслы, воплощение, итоги. Цікавим є доробок Констянтина Куцова під назвою Центральный Союз Подкарпаторусских Студентов (1928-1939) - Верховная структура русинского студенчества в межвоенной Чехословакии: краткая история, в якому автор знайомить нас зі заснуванням даної організації русинами, які в 1919 році опинилися у складі Чехословаччини, та труднощами, що супроводжували цей процес. Стаття є також внеском до історії чесько-українських відносин.

Актуальним в Україні і до сьогодні залишається мовна проблематика побутування суржика не лише на рівні щоденної комунікації, але також його проникнення до царини художніх літературних творів. Тому вибір даної теми Тетяною Миколаївною Курохтіною, яку авторка розглядає в статті Отображение суржика в украинской художественной литера туре, є важливим вкладом до даної проблеми, адже торкається такої делікатної для україн- ців теми, як суржик, на фонетичному, морфологічному, лексичному, стилістичному та синтаксичному рівнях на прикладі оповідань сучасного українського письменника Богдана Жолдака.

3 одного боку, збірник вражає калейдоскопічністю тем, розкриття яких відіграє важливу роль не лише в об'єктивізації питань історичного, культурного та мовного характеру, але також у розгляді контактів та взаємовпливів між Україною, Білорусією та Росією 3 акцентом на перших двох. 3 іншого - в опублікованих дослідженнях відсутній об'єднуючий тематичний критерій, який обмежується лише назвою самої книги.

Варто відзначити, що збірник має велике значення для укріплення українсько-російсько-білоруських зв'язків як на культурно-історичному, так лінгвістичному чи інших рівнях. Сподіваємося на вихід чергового збірника Украӥна $і$ Білорусія з новою добіркою актуальних, цікавих та різнопланових тем.

\section{Bc. et Bc. Olga Shytova}

Filozofická fakulta Masarykovy univerzity

Brno, Česká republika

396952@mail.muni.cz

PhDr. Petr Kalina, Ph.D.

Filozofická fakulta Masarykovy univerzity

Brno, Česká republika

kalina@phil.muni.cz 